\title{
CYCLIC TESTS ON MASONRY PIERS
}

\author{
R. L. Mayes*, N. M. Mostaghel**, R. W. Clough ${ }^{* * *}$, and W. L. Dickey ****
}

\begin{abstract}
SUMMARY
The paper describes the preliminary phase of an experimental investigation into the behaviour of reinforced masonry shear wall elements subjected to high speed cyclic loading. The three specimens tested in the preliminary phase were full scale wall panels about 4 meters square, each consisting of two piers connected by a top and bottom spandrel; each panel was made from a different material. The results of the tests on the three specimens are presented in the form of dynamic force deflection relationships.
\end{abstract}

The test equipment designed for the program is described in detail, and the next phase of the test program is outlined.

\section{INTRODUCTION}

In spite of being the oldest building material, the technological development of masonry in Earthquake Engineering has lagged behind that of other structural materials. The paucity of knowledge on the subject has led to a lack of confidence by engineers for its use in seismic resistant structures. This attitude has not been helped by a history of poor earthquake performance for "unengineered" masonry structures.

Most of the experimental evidence obtained to date on masonry structural elements has peen limited to monotonic loading $(1-14)$. The only major study known to the authors on the post elastic cyclic behaviour of masonry shear walls was performed by Williams (15). He compared the pseudo-static and dynamic cyclic behaviour of four different cantilever shear walls and concluded that, contrary to normally accepted opinion, cyclic pseudo-static test results may be inappropriate for use as a conservative basis for seismic design. Although the conclusion could only be considered as tentative, it emphasized the need for further studies on the dynamic cyclic behaviour of masonry shear wall elements.

This paper, which is a report on the preliminary phase of an extensive investigation, describes in detail the test specimen, procedure, and equipment chosen and developed for the experimental program. Some results of the preliminary tests are presented together with a linear range finite element analysis of the first test specimen. The test program is being

* Assistant Research Engineer, University of California, Berkeley. California.

** Visiting Research Engineer, Pahlevi University, Iran.

*** Director of Earthquake Research Center, University of California, Berkeley, California.

**** Consulting Structural Engineer, Masonry Institute of America. carried out at the Earthquake Engineering Research Center of the University of California, under sponsorship of the National Science Foundation and the Masonry Institute of America.

\section{TEST SPECIMEN}

The primary shear resisting elements of multistory reinforced masonry buildings are vertical cantilever, coupled shear walls and perforated shear walls such as those shown in Figure 1. The smallest structural components of interest are the single or double piered elements circled in Figure 1. A complete understanding of the earthquake behaviour of these elements will be of great help in developing a more realistic model of the entire perforated shear wall and in addition will aid in understanding the behaviour of the cantiliver and coupled shear walls. The advantage of the double pier element as a test specimen is that it is able to represent the reversal of the overturning moment when subjected to a cyclic load. The major disadvantage is the time and cost invovled in testing this larger element as compared with a single pier, but for the purpose of the preliminary investigation a double piered panel was chosen as the test specimen.

The three panels tested in the preliminary phase of the investigation are shown in Figures 2,3 and 4 . The piers of the panels were the elements of interest. The spandrels provided boundary conditions and overturning moments similar to those the piers would experience in an actual structure.

\section{PANEL NUMBER I (Figure 2)}

Panel Number 1 was constructed from standard two-core reinforcible concrete blocks of nominal 8" by 8 " by $16 "$ dimensions. Each core was approximately 30 square inches in area. The ratio of net to gross area was 49.58 . Single units had a compressive strength of 3615 psi on the net area and a tensile strength of 206 psi measured by the California Q-Block 
Quality Control Specifications. A cementlime mortar (4 Sand: 1 Cement: 1/2 lime by Volume) with 28 day strength of $4650 \mathrm{psi}$ was used. The cores of the piers containing reinforcement and all cores of the top and bottom spandrels were grouted. The 28 day strength of the grout was 3960 psi. In addition two sets of 3 block high prisms were constructed. The ungrouted prisms were tested at 28 days and had an average net compressive strength of $2294 \mathrm{psi}$. The grouted prisms were tested at the same time as the panel, 5 months after construction. The ultimate net compressive stress of the grouted prisms was $3829 \mathrm{psi}$. The secant modulus of elasticity at $40 \%$ of the ultimate stress was $2.1 \times 10^{6}$ psi.

Panel Number 2 (Figure 3)

Panel Number 2 was constructed from standard two-core reinforcible hollow clay bricks of nominal 4" by 8 "by 12" dimensions. The area of each core was approximately 15 $3 / 4$ square inches and the ratio of net to gross area was $64 \%$. Single units had a net compressive strength of $4980 \mathrm{psi}$, a tensile strength of 217 psi measured by the California Q-Block Quality Control Specifications, and an initial rate of absorption of $24 \mathrm{gm} / 30 \mathrm{sq}$. in/min. A cement/lime mortar ( 4 Sand: 1 Cement: $1 / 2$ lime by Volume) with 28 day strength of 3045 psi was used in constructing the test panel. The cores of the piers containing reinforcement and all cores of the top and bottom spandrels were grouted. The 28 day strength of the grout was $6365 \mathrm{psi}$. In addition two sets of 3 block high prisms were constructed. The ungrouted prisms were tested at 28 days and the average net compressive strength was 4400 psi. The grouted prisms were tested at the same time as the panel, 5 months after construction. The ultimate net compressive strength was $3773 \mathrm{psi}$ and the secant modulus of elasticity at $40 \%$ of the ultimate strength was $2.0 \times 10^{6}$ psi.

Panel Number 3 (Figure 4)

Panel Number 3 was constructed from solid clay brick units of nominal 3" by 4 " by 12" dimensions. Single units had a net compressive strength of $5455 \mathrm{psi}$ and an initial rate of absorption of $21 \mathrm{gm} / 30 \mathrm{sq}$. in/min. The test panel was constructed of two leaves of the brick units with a $31 / 4$ inch thick grouted core between. The two brick leaves were connected by No. 2 steel ties placed 24 inches apart horizontally and in every third course vertically. The horizontal and vertical reinforcement was placed in the grouted core. Two $91 / 2$ " by 13" grouted prisms of similar construction were tested at the same time as the panel - 5 months after construction. The ultimate net compressive strength was 4365 psi and the secant modulus at $40 \%$ of the ultimate strength was $1.845 \times 10^{6}$ psi.

\section{TEST EQUIPMENT AND PROCEDURE}

The test equipment shown in Figure 5 , permits lateral loads to be applied in the plane of the piers in a manner similar to that in which a floor diaphram would load the piers during earthquake excitation. It consists of two twenty feet high, heavily braced reaction frames to which a pair of hydraulic actuators are connected, a mechanism capable of applying vertical bearing loads similar to those experienced by the piers in an actual structure, and a concrete base on which the panel is constructed and bolted to the test floor.

The maximum dynamic load which may be developed by the actuators (at 3000 psi oil pressure) is $60 \mathrm{Kips}$ (maximum static load at same pressure is $76.2 \mathrm{kips}$ ). The maximum stroke is \pm 6 in. , the maximum piston velocity is $26 \mathrm{in} / \mathrm{sec}$. and the flow capacity of the servovalves is $200 \mathrm{gpm}$. The actuator has the option of being controlled with regard to either displacement or load. The operational capabilities of actuators are limited by the above mentioned force capacity, and also by a frequency limitation of about $5 \mathrm{~Hz}$. All experiments had to be designed within these limitations.

A total vertical load of $160 \mathrm{Kips}$ can be applied to each pier through the springs and rollers shown in Figure 5. The Thomson Dual Roundway Bearings connecting the springs to the top of the panel allow the panel to move freely with a minimal friction force. The coefficient of the friction of the bearings is approximately .007 .

Each panel was constructed on a $20 \mathrm{ft}$. $\mathrm{x} 4 \mathrm{ft} . \mathrm{x} 2 \mathrm{ft}$. concrete base which allowed the panels to be moved into place after construction and bolted to the test floor.

The deflections of each pier were measured by potentiometers and LVDT's attached to the reference frames placed at either end of the panels. The deflection at the top, bottom and third points of the outside edge of each pier were measured. The top and bottom measurements were assumed to represent the deflection at the centre points of the pier and were used to calculate the relative deflection. It was clear that this assumption was valid until large cracks developed on the diagonal. Fortunately this only occurred on the last sequence of loading for each panel.

The loading sequence of each panel consisted of 3 sinusoidal cycles of load applied at a specified amplitude and frequency. After each set of 3 cycles of loading, the walls were visually inspected and the crack pattern identified. The increment of input displacement specified for the next 3 cycles was dependent upon the state of damage of the piers at that particular stage. This process was repeated until the piers were unable to withstand any further horizontal load. The only problem encountered in the loading sequence was due to the fact that the displacement of the piers was controlled by the displacement of the actuators. When the actuators were pushing the panel away from the frame, the deflections in the loading system were due to the reaction frame and loading beam. In the reverse cycle the actuators were pulling the panel towards the frame and additional deflections arose from tension placed on the bolting system. The effect was most pronounced at higher loads and resulted in larger positive deflections in a given 
loading sequence.

\section{COMPUTER ANALYSIS}

A finite element analysis of panel Number 1 was performed (16), using equivalent linear material properties and treating the masonry wall as a homogeneous medium. The wall was modelled as an assemblage of plane stress and truss elements. The truss elements were used to model the reinforcing steel. The distribution of shear and principal tensile stresses of the right hand side pier are shown in Figure 6. The analysis was done prior to the test to get a better idea of the initial stiffness and probable location of the initial cracks. It was assumed that the regions of maximum principal tensile stress would give an indication of location of these cracks.

To be able to perform a more detailed non-linear finite element analysis, an adequate and realistic failure criterion must be developed for masonry under combined stress conditions.

\section{RESULTS}

Three possible failure modes may be identified for the piers. The first, the diagonal tension or shear mechanism, is characterized by diagonal or $x$ cracks. The second, the tension, yield or secondary compressive mechanism is similar to the tension failure of a column. It is characterized by a compressive failure at the toe of the pier due to substantial yielding of the tensile steel. The third and least likely mechanism is a compressive failure. It is characterized by tensile splitting of the material in regions of high compressive stress, similar to that experienced in prism tests.

Photographs of the failed state of Panels 2 and 3 , (Figures 7 and 8 ) indicate two of the above modes of failure. Panel Number 2, consisting of two piers with a height to width ratio of two indicate the combined diagonal tension and secondary compressive mechanisms. The loss of confinement and buckling of the vertical steel at the toe of the piers is indicative of the secondary compressive failure. Panel Number 3, consisting of piers with a height to width ratio of one, failed in simple diagonal tension.

The experimental results of the cyclic tests on the three panels are presented in the form of hysteresis curves in Figures 9,10 and 11. The frequency of load application for panels 1,2 and 3 was 3 cps, $0.5 \mathrm{cps}$ and 0.1 cps respectively. The hysteresis curve for Panel Number 3 does not include the last (i.e. failure) sequence of loading. The LVDT's were removed to prevent damage of the instruments similar to that which had occurred in the first tests. This limitation necessitated a redesign of the method of measuring the deflections of the piers in future tests. The vertical load on each pier for the three tests was equivalent to a bearing stress of 125, 125 and 375 psi respectively. tests, the deflections measured on Panels $I$ and 2 were not as accurate as desired. The deflections measured on Panel Number 3 are accurate to within $\pm 5 \%$. The loads in all tests were accurate to within $\pm 2 \%$.

To give an indication of the stiffness degradation occurring during each cycle of loading, a stiffness coefficient defined as

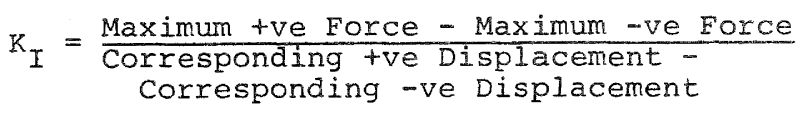

is presented in Table 1. Although the stiffness degradation was substantial in all three panels, this behaviour should be considered in conjunction with the maximum horizontal load. For the piers of Panel Number 1 a severe drop in the load carrying capacity occurred in the second to last sequence of loading in the positive direction. The piers of Panels 2 and 3 were capable of withstanding the maximum horizontal load until the last or failure sequence of loading. As observed from Williams' (15) results, this desirable property of the piers is dependent upon the sequence of load application, and emphasizes the necessity of including different loading sequences as a parameter in future studies.

The maximum net shear stress developed in each panel, based on the maximum horizontal load and the net area of each pier were as follows: - Panel No. 1 - 250 psi; Panel No. 2 - 120 psi; Panel No. 3 - 190 psi.

\section{NEXT PHASE OF THE TEST PROGRAM}

The next phase of the investigation will include 8 to 10 tests on Panels of dimensions similar to those of Panel No. 2 . The variables to be considered will include the effect of loading rate, horizontal shear reinforcement, bearing load and a comparison between the shear and yield failure mechanisms. Because of the load limitation of the actuators the piers will be constructed from 6 inch concrete blocks with dimensions $5^{\prime}-6^{\prime \prime}$ high and 2'-8" wide. In addition to the load limitation, the time and expense involved in testing the full size panels has made it desirable to conduct a secondary program simultaneously on individual full size piers. The top and bottom support conditions of the piers will simulate those of the piers in the panel insofar as possible. The one or two days required to test such elements will permit a larger number of parameters to be studied; these will include: 1) Geometry of the piers; 2) Effects of different materials and material strengths: 3) Quantity and distribution of reinforcement; 4) Rate of load application; 5) Sequence of loading; 6) Bearing Stress; 7) Quality of Workmanship.

\section{CONCLUSIONS}

The test equipment and method, presented and utilised for determining the dynamic characteristics of masonry panels was considered adequate although limited somewhat by the actuators. The unique feature of the method presented is the 
ability of the panels to simulate the dynamic variation in the vertical load on the individual piers, which results from the overturning moment developed in the complete system.

\section{REFERENCES}

1. Blume, J. A. and Prolux, J., "Shear in Grouted Brick Masonry Wall Elements", Report to Western States Clay Products from J. A. Blume and Associates, August, 1968.

2. Borchelt, J. G., "Analysis of Brick Walls Subjected to Axial Compression and in Plane Shear". Proceedings of Second International Brick Masonry Conference, Stoke-on-Trent, April, 1970.

3. Greenley, D. G. and Cattaneo, L. E., "The Effect of Edge Load on the Racking Strength of Clay Masonry", Proceedings of Second International Brick Masonry Conference, Stoke-on-Trent, April, 1970 .

4. Haller, P., "Load Capacity of Brick Masonry", Designing, Engineering and Constructing with Masonry Products, Edited by F. B. Johnson, May, 1969.

5. Kalita, U. C. and Hendry, A. W. "An Experimental and Theoretical Investigation of the Stresses and Deflections in Model Cross Wall Structures," Proceedings of the second International Brick Masonry Conference, Stoke-on-Trent, April, 1970.

6. Moss, P. J. and Scrivener, J. C., "Masonry Wall Panel Tests", New Zealand Concrete Construction, April, 1968.

7. Pieper, K. and Trautsch, W., "Shear Tests on Walls", Proceedings of Second International Brick Masonry Conference, Stoke-on-Trent, April, 1970.

8. Schneider, R. R. " "Lateral Load Tests on Reinforced Grouted Masonry Shear Walls", University of Southern California Engineering Center, Report No. 70-101, 1959.

9. Schneider, R. R., "Shear in Concrete Masonry Piers", California State Polytechnic College, Pomona, California 1969.

10. Scrivener, J. C., "Concrete Masonry Wall Panel Tests with Predominant Flexural Effect", New Zealand Concrete Construction, July, 1966.

11. Scrivener, J. C.," "Static Racking Tests on Concrete Masonry Walls", Designing, Engineering and Constructing with Masonry Products, Edited by F. B. Johnson, May, 1969.

12. Sinha, B. P., and Hendry, A. W. "Racking Tests on Story Height Shear Wall Structures with Openings, Subjected to Precompression", Designing, Engineering and constructing with Masonry Products, Edited by F. B. Johnson, May, 1969.

13. Sinha, B. P., Maurenbrecher, A. H. P. and Hendry, A. W., "Model and Full Scale Tests on a Five Story cross Wall Structure under Lateral Loading", Proceedings of Second International Brick Masonry Conference, Stoke-on-Trent, April, 1970.

14. Turnsek, V. and Cacovic, F., "Some Experimental Results on the Strength of Brick Masonry Walls", Proceedings of Second International Brick Masonry Conference, Stoke-on-Trent, April, 1970.
15. Williams, D. W., "Seismic Behaviour of Reinforced Masonry Shear Walls". Ph.d Thesis, University of Canterbury, Christchurch, New Zealand.

16. Mostaghel, N. M., Mayes, R. L. and Clough, R. W., "Determination of Equivalent Material Properties for Masonry", EERC Report in Preparation, University of California, Berkeley, California. 
TABLE 1.

TEST PANEL 1

TEST PANEL 2

TEST PANEL 3

\begin{tabular}{|c|c|c|c|c|c|c|c|c|c|c|c|c|c|c|}
\hline \multicolumn{2}{|c|}{$\begin{array}{c}\text { MAXIMUM } \\
\text { FORCE-KIPS }\end{array}$} & \multicolumn{2}{|c|}{$\begin{array}{l}\text { CORRESPONDING } \\
\text { DISPL. - IN. }\end{array}$} & \multirow[t]{2}{*}{$\stackrel{\mathrm{K}_{\mathrm{I}}}{\mathrm{KIPS} / \mathrm{IN} .}$} & \multicolumn{2}{|c|}{$\begin{array}{c}\text { MAXIMUM } \\
\text { FORCE-KIPS }\end{array}$} & \multicolumn{2}{|c|}{$\begin{array}{l}\text { CORRESPONDING } \\
\text { DISPL. - IN. }\end{array}$} & \multirow[t]{2}{*}{$\frac{\mathrm{K}_{\mathrm{I}}}{\mathrm{KIPS} / \mathrm{IN} .}$} & \multicolumn{2}{|c|}{$\begin{array}{c}\text { MAXIMUM } \\
\text { FORCE-KIPS }\end{array}$} & \multicolumn{2}{|c|}{$\begin{array}{l}\text { CORRESPONDING } \\
\text { DISPL. - IN. }\end{array}$} & \multirow[t]{2}{*}{$\frac{\mathrm{K}_{\mathrm{I}}}{\mathrm{KIPS} / \mathrm{IN} .}$} \\
\hline +ve & -ve & tve & -ve & & tve & -ve & +ve & -ve & & tve & -ve & tve & -ve & \\
\hline $\begin{array}{l}25.3 \\
24.7 \\
24.6\end{array}$ & $\begin{array}{l}24.8 \\
24.9 \\
24.9\end{array}$ & $\begin{array}{l}.0138 \\
.0138 \\
.0138\end{array}$ & $\begin{array}{l}.0150 \\
.0150 \\
.0150\end{array}$ & $\begin{array}{l}1742 \\
1722 \\
1719\end{array}$ & $\begin{array}{l}18.2 \\
17.9\end{array}$ & $\begin{array}{l}20.8 \\
19.6\end{array}$ & $\begin{array}{l}.100 \\
.110\end{array}$ & $\begin{array}{l}.100 \\
.110\end{array}$ & $\begin{array}{l}194 \\
170\end{array}$ & $\begin{array}{l}15.5 \\
15.8 \\
15.8\end{array}$ & $\begin{array}{l}16.7 \\
15.5 \\
16.4\end{array}$ & $\begin{array}{l}.0056 \\
.0049 \\
.0049\end{array}$ & $\begin{array}{l}.0046 \\
.0050 \\
.0046\end{array}$ & $\begin{array}{l}3379 \\
3484 \\
3351\end{array}$ \\
\hline $\begin{array}{l}35.6 \\
32.3 \\
31.4\end{array}$ & $\begin{array}{l}33.5 \\
32.6 \\
32.3\end{array}$ & $\begin{array}{l}.046 \\
.048 \\
.048\end{array}$ & $\begin{array}{l}.046 \\
.046 \\
.046\end{array}$ & $\begin{array}{l}744 \\
689 \\
676\end{array}$ & $\begin{array}{l}18.5 \\
18.3 \\
17.6\end{array}$ & $\begin{array}{l}20.6 \\
19.7 \\
19.4\end{array}$ & $\begin{array}{l}.156 \\
.155 \\
.168\end{array}$ & $\begin{array}{l}.160 \\
.155 \\
.155\end{array}$ & $\begin{array}{l}123 \\
123 \\
115\end{array}$ & $\begin{array}{l}30.9 \\
30.3 \\
29.7\end{array}$ & $\begin{array}{l}29.4 \\
30.0 \\
28.2\end{array}$ & $\begin{array}{l}.0127 \\
.0111 \\
.0141\end{array}$ & $\begin{array}{l}.0093 \\
.0109 \\
.0122\end{array}$ & $\begin{array}{l}2737 \\
2732 \\
2200\end{array}$ \\
\hline $\begin{array}{l}46.5 \\
45.0 \\
44.1\end{array}$ & $\begin{array}{l}47.3 \\
44.0 \\
45.3\end{array}$ & $\begin{array}{l}.116 \\
.116 \\
.116\end{array}$ & $\begin{array}{l}.108 \\
.105 \\
.101\end{array}$ & $\begin{array}{l}417 \\
401 \\
411\end{array}$ & $\begin{array}{l}19.6 \\
19.1 \\
18.5\end{array}$ & $\begin{array}{l}21.2 \\
20.9 \\
20.6\end{array}$ & $\begin{array}{l}.200 \\
.200 \\
.190\end{array}$ & $\begin{array}{l}.188 \\
.180 \\
.187\end{array}$ & $\begin{array}{l}105 \\
105 \\
104\end{array}$ & $\begin{array}{l}55.3 \\
54.8 \\
54.6\end{array}$ & $\begin{array}{l}49.2 \\
49.2 \\
48.8\end{array}$ & $\begin{array}{l}.0296 \\
.0319 \\
.0350\end{array}$ & $\begin{array}{l}.0196 \\
.0144 \\
.0176\end{array}$ & $\begin{array}{l}2124 \\
2243 \\
1961\end{array}$ \\
\hline $\begin{array}{l}48.2 \\
37.3 \\
25.7\end{array}$ & $\begin{array}{l}49.7 \\
48.5 \\
46.0\end{array}$ & $\begin{array}{l}.181 \\
.223 \\
.179\end{array}$ & $\begin{array}{l}.174 \\
.177 \\
.187\end{array}$ & $\begin{array}{l}275 \\
214 \\
187\end{array}$ & $\begin{array}{l}21.5 \\
21.0 \\
19.9\end{array}$ & $\begin{array}{l}23.9 \\
23.0 \\
23.1\end{array}$ & $\begin{array}{l}.288 \\
.275 \\
.275\end{array}$ & $\begin{array}{l}.250 \\
.263 \\
.250\end{array}$ & $\begin{array}{l}85 \\
82 \\
82\end{array}$ & $\begin{array}{l}61.7 \\
61.2 \\
60.6\end{array}$ & $\begin{array}{l}55.8 \\
47.6 \\
55.7\end{array}$ & $\begin{array}{l}.120 \\
.120 \\
.125\end{array}$ & $\begin{array}{l}.056 \\
.056 \\
.056\end{array}$ & $\begin{array}{l}669 \\
619 \\
641\end{array}$ \\
\hline \multirow[t]{2}{*}{$\begin{array}{r}26.4 \\
2.2 \\
1.3\end{array}$} & $\begin{array}{r}23.6 \\
3.2 \\
1.6\end{array}$ & $\begin{array}{l}.45 \\
.49 \\
.49\end{array}$ & $\begin{array}{l}.45 \\
.52 \\
.53\end{array}$ & $\begin{array}{r}57.7 \\
5.3 \\
2.9\end{array}$ & $\begin{array}{l}19.9 \\
19.0\end{array}$ & $\begin{array}{l}24.6 \\
22.6 \\
21.6\end{array}$ & $\begin{array}{l}.388 \\
.387\end{array}$ & $\begin{array}{l}.325 \\
.325 \\
.338\end{array}$ & $\begin{array}{l}62 \\
57 \\
53\end{array}$ & $\begin{array}{l}65.3 \\
64.8 \\
64.2\end{array}$ & $\begin{array}{l}61.2 \\
60.5 \\
59.4\end{array}$ & $\begin{array}{l}.139 \\
.151 \\
.158\end{array}$ & $\begin{array}{l}.069 \\
.069 \\
.071\end{array}$ & $\begin{array}{l}611 \\
569 \\
540\end{array}$ \\
\hline & & & & & & & & & & $\begin{array}{l}64.1 \\
63.0 \\
63.0\end{array}$ & $\begin{array}{l}66.6 \\
66.6 \\
67.9\end{array}$ & $\begin{array}{l}.157 \\
.177 \\
.202\end{array}$ & $\begin{array}{l}.106 \\
.067 \\
.086\end{array}$ & $\begin{array}{l}498 \\
537 \\
454\end{array}$ \\
\hline
\end{tabular}




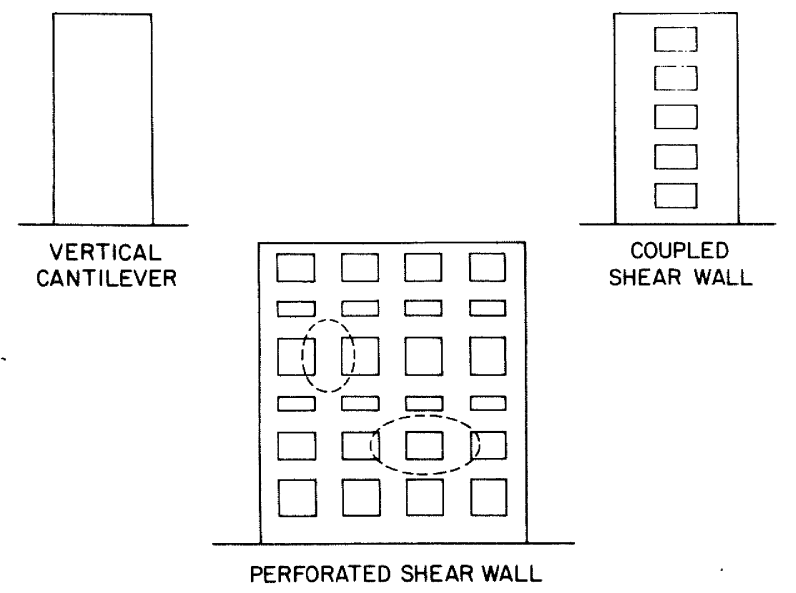

FIGURE 1

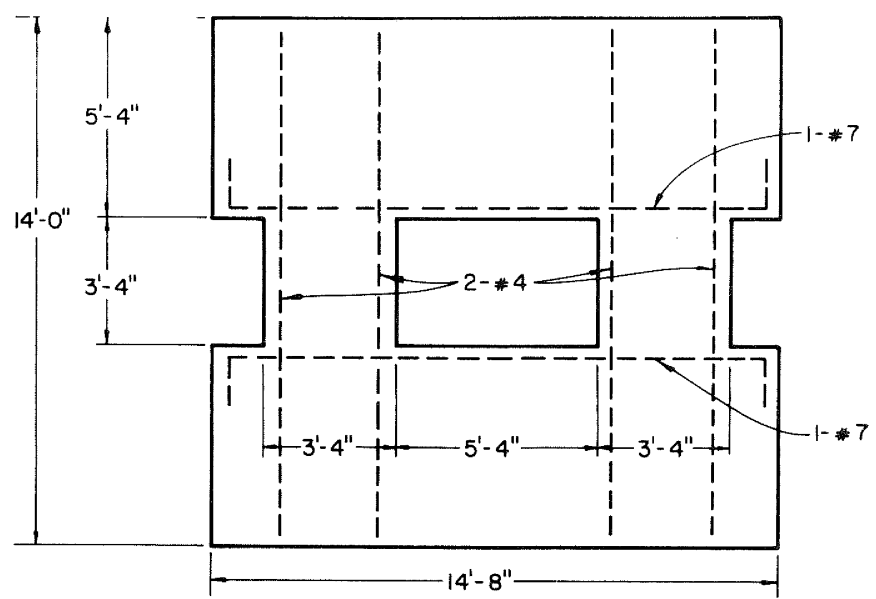

PANEL NO. $1: 8 " \times 8 " \times 16 "$ CONCRETE BLOCKS

FIGURE 2

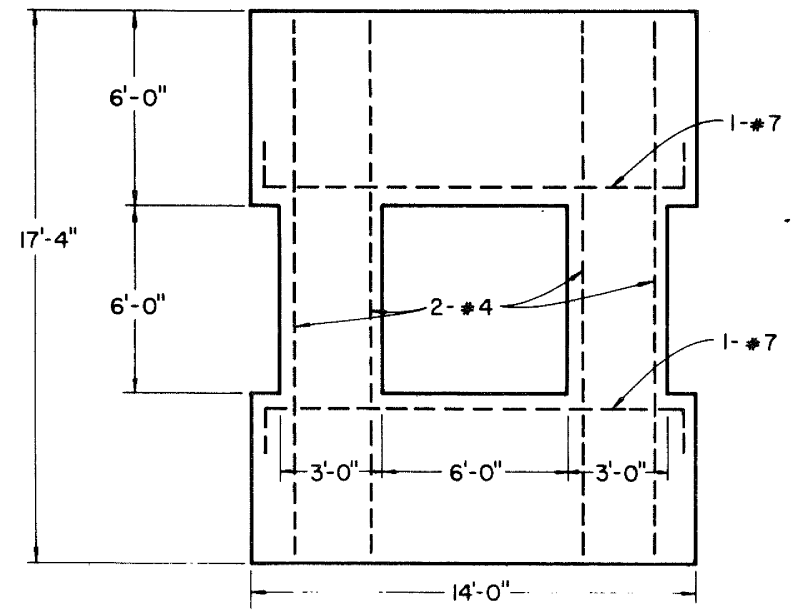

PANEL NO. $2: 4 " \times 8 " \times 12^{\prime \prime}$ CLAY BRICKS

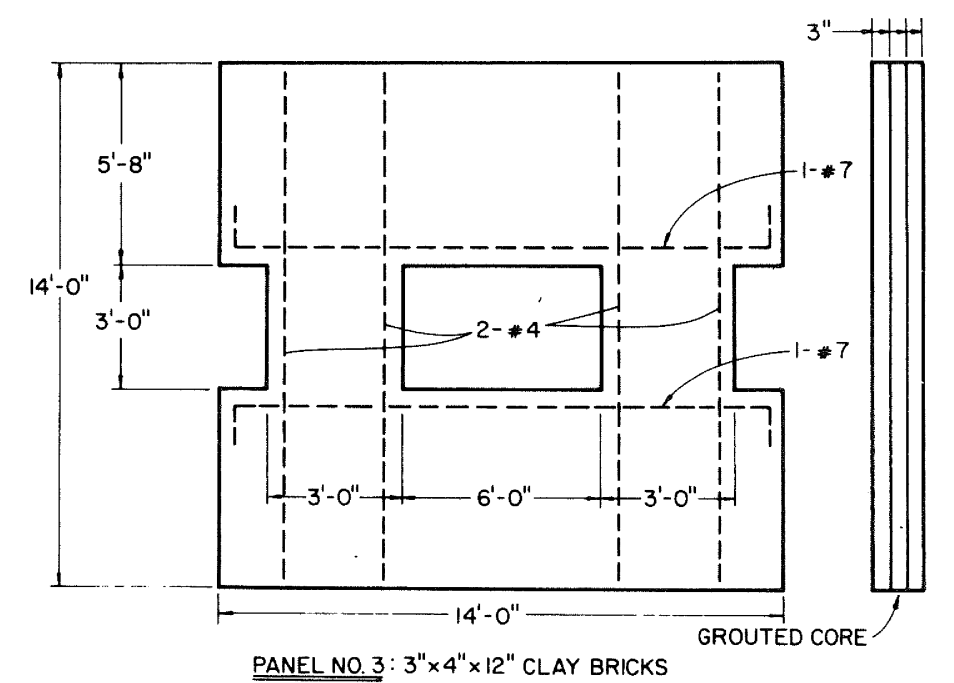

PANEL NO. $3: 3^{\prime \prime} \times 4^{\prime \prime} \times 12 "$ CLAY BRICKS 


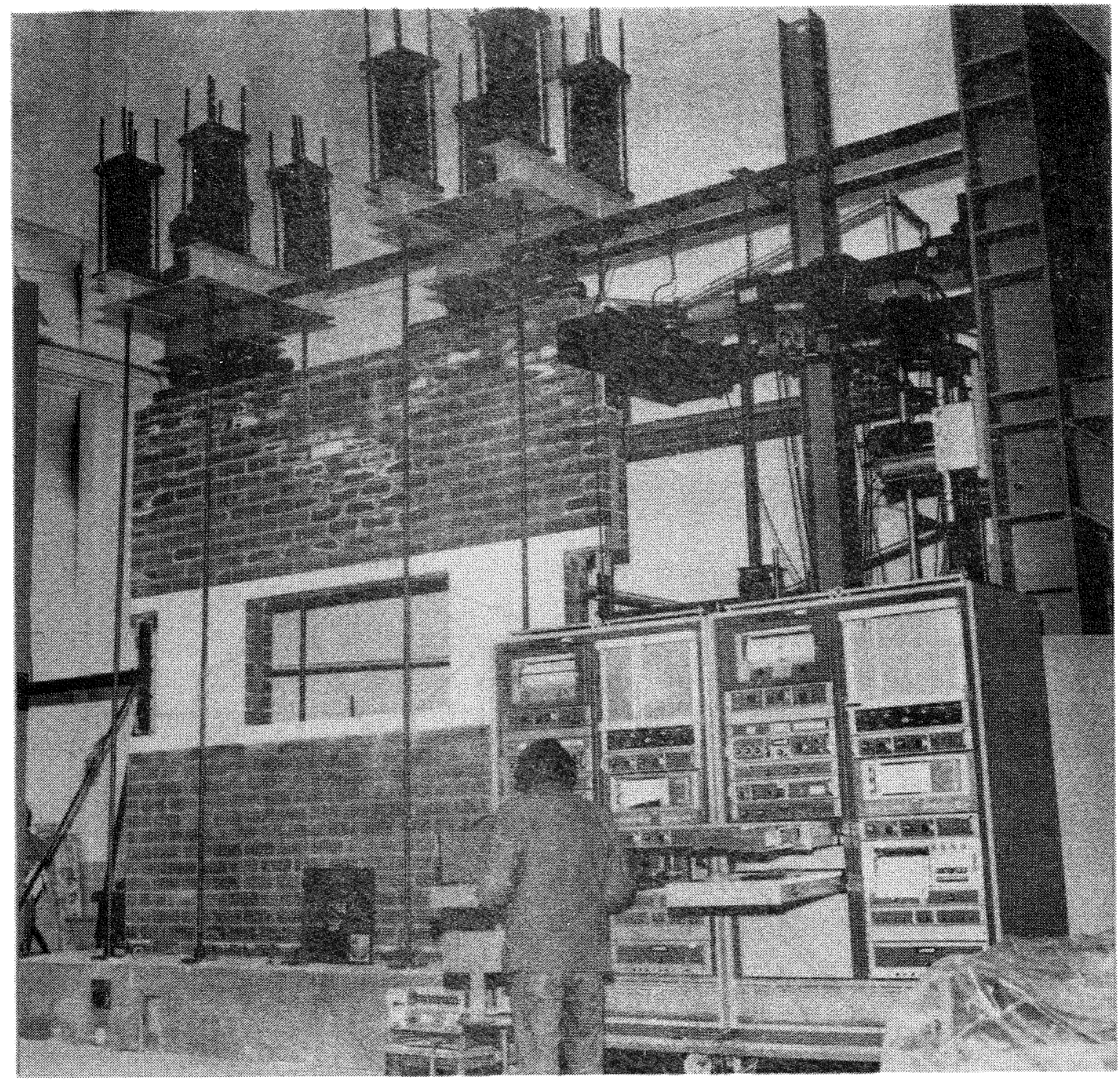

FIGURE 5: TEST EQUIPMENT 


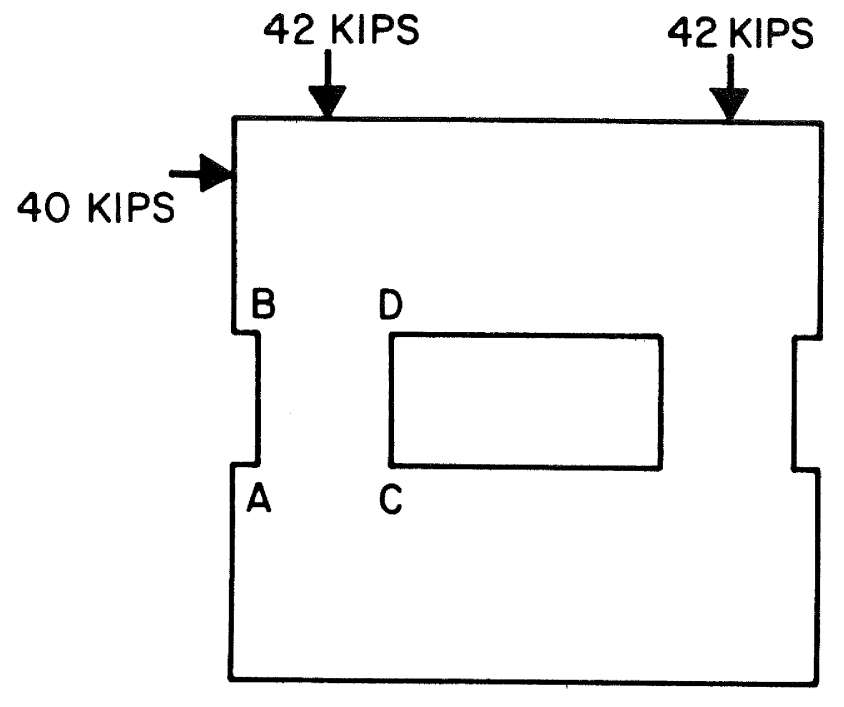

a) APPLIED LOADS

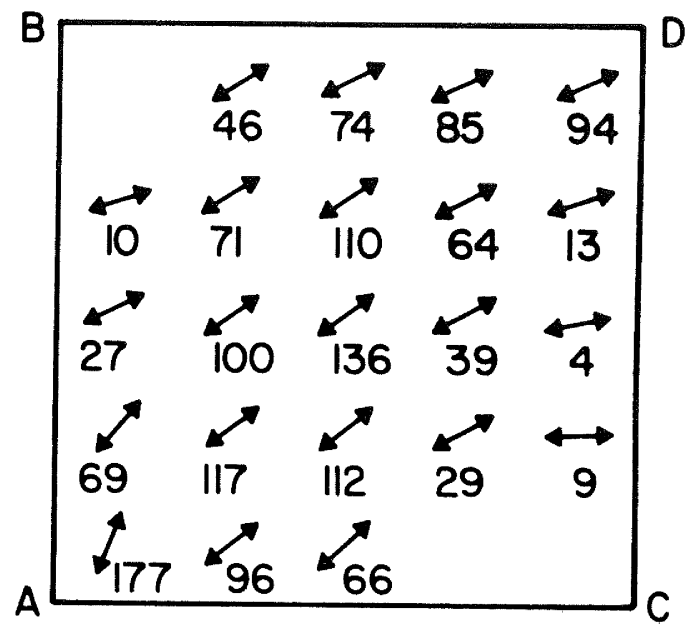

b) PRINCIPAL TENSILE STRESSES - PSI

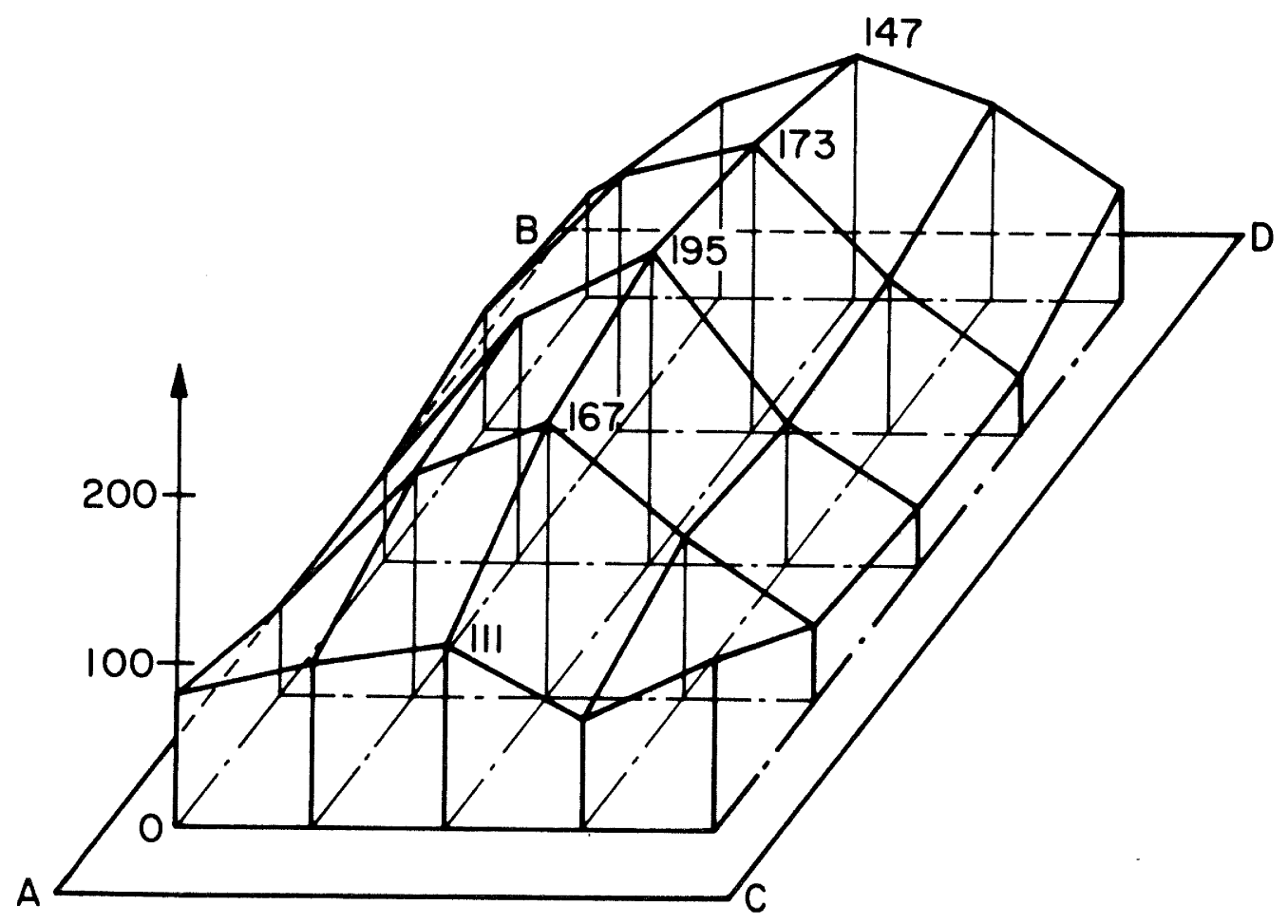

c) SHEAR STRESSES - PSI 

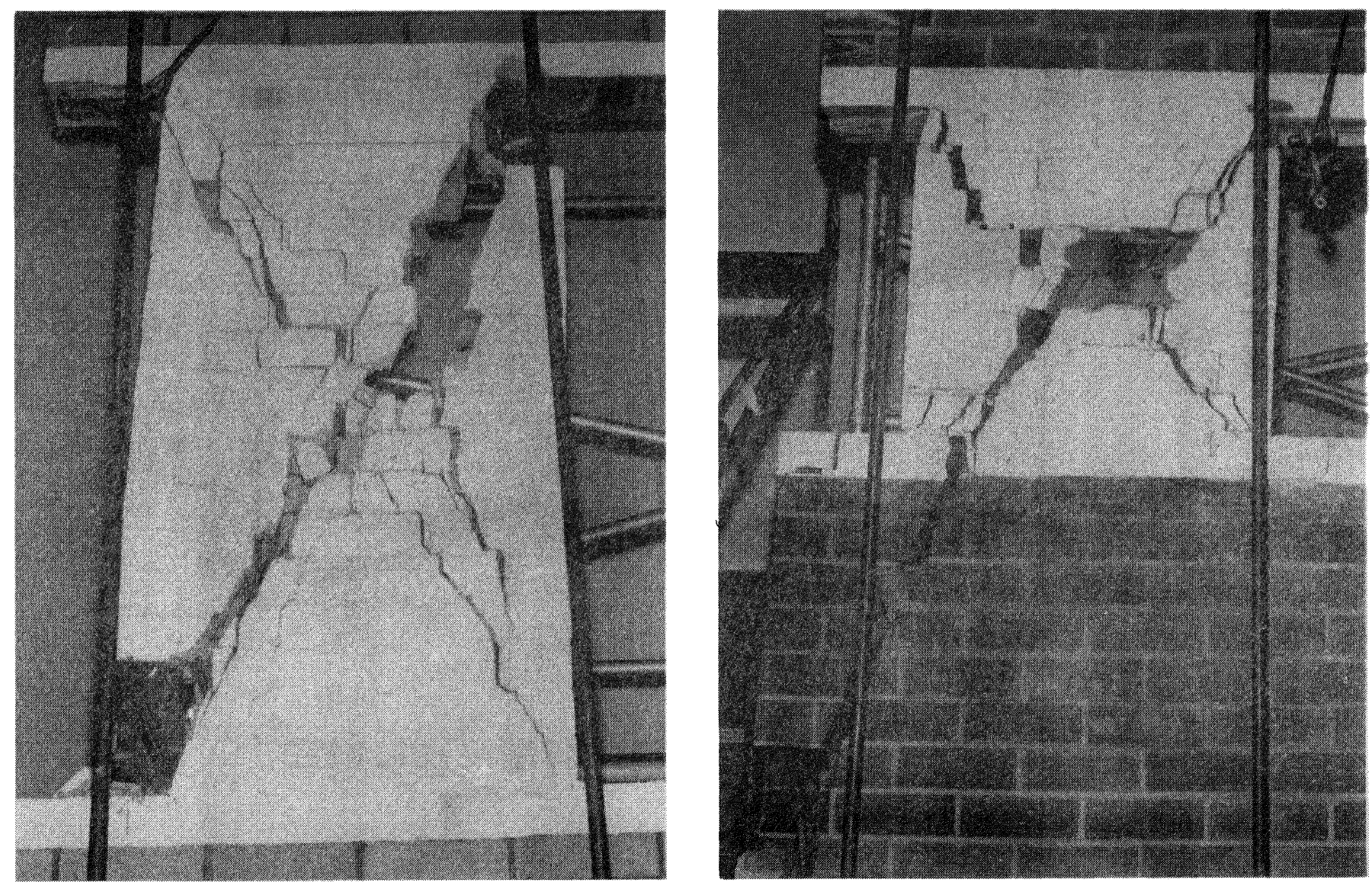

FIGURE 7: TEST PANEL NO.2

FIGURE 8: TEST PANEL NO.3 

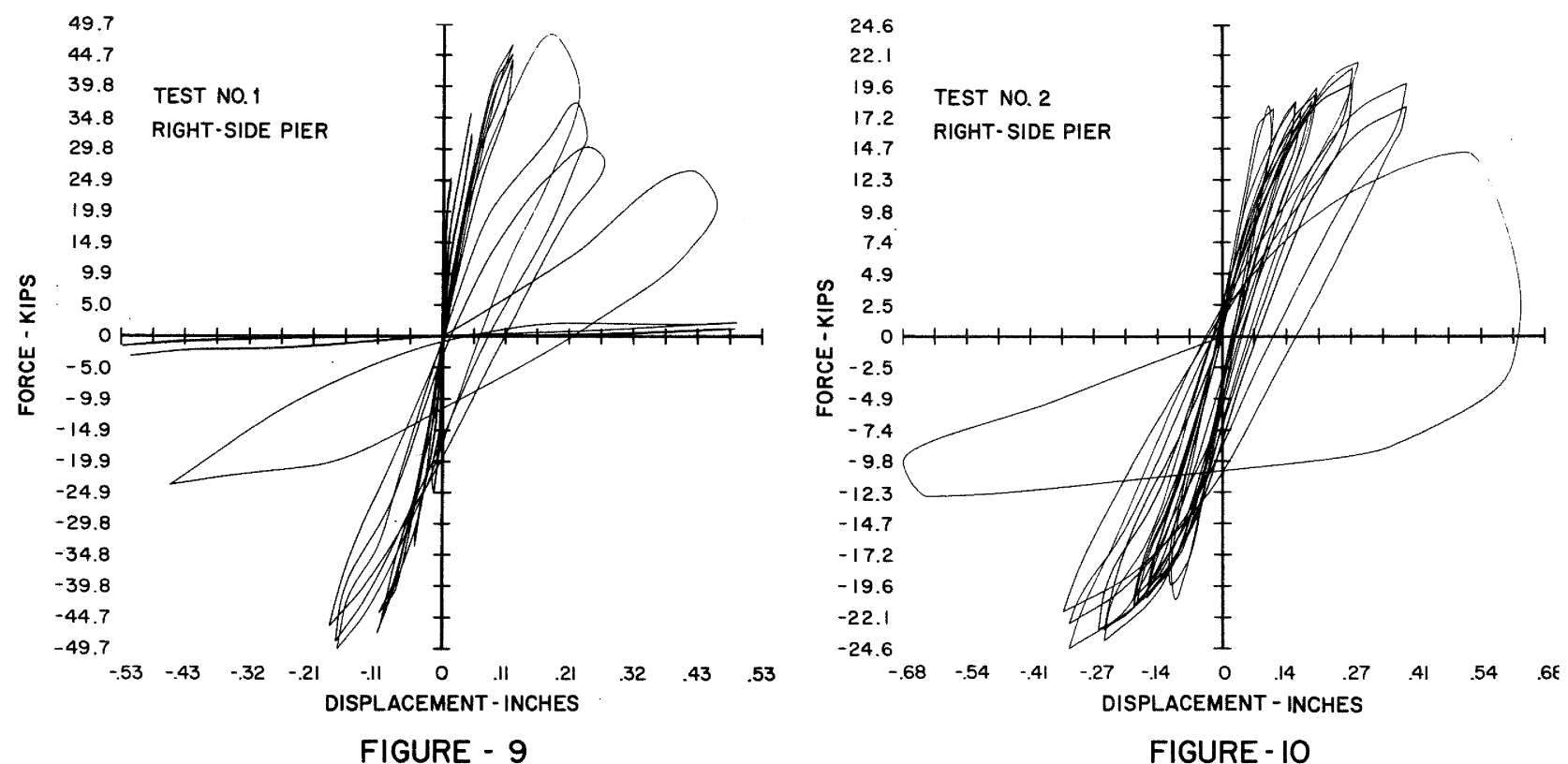

FIGURE - 9

FIGURE - IO

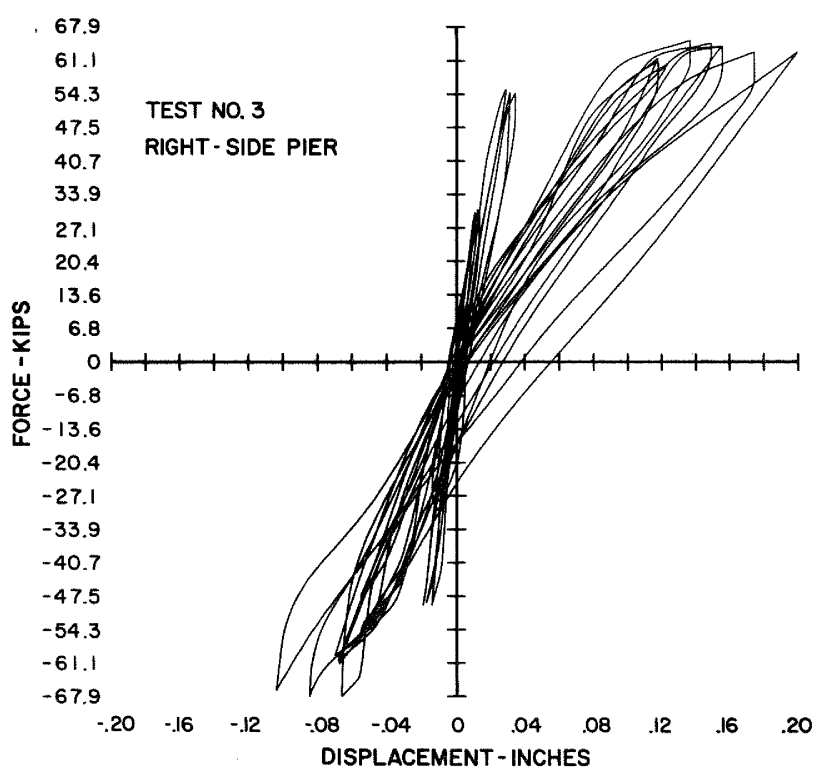

FIGURE - II 